\title{
ANALISIS KEBUTUHAN TENAGA REKAM MEDIS MENGGUNAKAN METODE WORKLOAD INDICATOR STAFF NEED (WISN) DI UPTD PUSKESMAS WERU TAHUN 2020
}

\author{
Sri Wahyuningsih ${ }^{1 *}$, Fahmi Hakam², Yul Asriati ${ }^{3}$ \\ ${ }^{123}$ Prodi Rekam Medis dan Informasi Kesehatan, Fakultas Kesehatan Masyarakat \\ Universitas Veteran Bangun Nusantara \\ *email : srywahyu17@gmail.com
}

\begin{abstract}
The Workload Indicator Staff Need (WISN)is an indicator that shows the amount of staff needed at health facilities based on workload, so that location or relocation will be easier and more rational. There is medical record officer at the UPTD health center Weru in the outpatient registration section who continues his education so that in his work duties must be replaced by officers in the filing division. Filing officers concurrently have duties as registration officers. Cause the workload of officers is high and officers in carrying out their duties are not in accordance with the established SOP. The purpose of this study was to calculate available working time, workload standards, allowance standards and the need for medical record personel at the UPTD health center Weru. This type of research is a descriptive study with a cross sectional approach.. The subjects in this study were 3 medical record staff and the object was the medical record staff. Data collection was carried out by observation and interviews with medical record officers at the UPTD health center Weru. The research instrument was an observation cheklist and interview guidelines.The calculation is done using the WISN method. It is known that the available working time is 1,925 hours / year or 115,500 minutes / year, the need for the workload for outpatient registration is 452,375 minutes, the filing section is 2.749 .542 minutes, the inpatient registration section or the emergency room is 420,063 minutes. The standard calculation of allowance is 0.15 hours / year, the calculation of the need for personnel is 5 personnel, so it is necessary to add 1 officer in the outpatient registration section of the UPTD healt center Werut.
\end{abstract}

Keyword : WISN, The need for medical record personnel, Workload

\begin{abstract}
ABSTRAK
Metode Workload Indicator Staff Need (WISN) merupakan indikator yang menunjukkan besarnya kebutuhan petugas pada sarana kesehatan berdasarkan beban kerja, sehingga lokasi atau relokasi akan lebih mudah dan rasional. Terdapat petugas rekam medis di UPTD Puskesmas Weru bagian pendaftaran rawat jalan yang melanjutkan pendidikannya sehingga dalam tugasnya bekerja harus digantikan oleh petugas dibagian filing. Petugas filing merangkap tugasnya menjadi petugas pendaftaran. Menyebabkan beban kerja dari petugas tinggi dan petugas dalam menjalankan tugasnya tidak sesuai dengan SOP yang telah ditetapkan.Tujuan penelitian ini yaitu untuk menghitung waktu kerja tersedia, standar beban kerja, standar kelonggaran dan kebutuhan tenaga rekam medis di UPTD Puskesmas Weru.Jenis Penelitian yang digunakan adalah penelitian deskriptif dengan pendekatan cross sectional. Subjek dalam penelitian ini yaitu 3 orang petugas rekam medis dan objeknya adalah kegiatan tenaga rekam medis. Pengumpulan data dilakukan dengan observasi dan wawancara terhadap petugas rekam medis di UPTD Puskesmas Weru. Instrumen penelitian dalam penelitian ini adalah checklist observasi dan pedoman wawancara. Penghitungan dilakukan dengan metode WISN. Diketahui waktu kerja tersedia 1.925 jam/tahun atau 115.500 menit/ tahun, kebutuhan beban kerja bagian pendaftaran rawat jalan 452.375 menit, bagian filing 2.749 .542 menit, bagian pendaftaran rawat inap atau UGD 420.063 menit. Penghitungan standar kelonggaran adalah 0,15 jam/tahun, penghitungan kebutuhan tenaga yaitu 5 tenaga, jadi perlunya penambahan 1 petugas di bagian pendaftaran rawat jalan UPTD Puskesmas Weru.
\end{abstract}

Kata Kunci: WISN, Kebutuhan tenaga rekam medis, Beban kerja 


\section{PENDAHULUAN}

Fasilitas pelayanan kesehatan adalah suatu tempat yang digunakan untuk menyelenggarakan upaya pelayanan kesehatan, baik promotif, preventif, kuratif maupun rehabilitatif yang dilakukan oleh pemerintah, pemerintah daerah dan atau masyarakat. Puskesmas adalah fasilitas pelayanan kesehatan yang menyelenggarakan upaya kesehatan masyarakat dan upaya kesehatan perseorangan tingkat pertama, dengan lebih mengutamakan upaya

promotif di wilayah kerjanya (Permenkes RI No. 43 Tahun 2019) Sutadji (2010) menyatakan bahwa perencanaan sumberdayamanusia(SDM) adalah proses sistematik yang digunakan untuk memprediksi dan menentukan jumlah kebutuhan serta penyediaan SDM pada saat ini dan masa yang akan datang.

Berdasarkan hasil studi pendahuluan pada tanggal 13 Januari 2020 diketahui bahwa tenaga yang tersedia di UPTD Puskesmas Weru pada bagian rekam medis berjumlah 7 orang, namun hanya 1 orang yang memiliki kualifikasi pendidikan D3 Rekam Medis. Tenaga tersebut terdiri dari 1 orang yang bertugas di bagian pendaftaran rawat jalan, 3 orang yang bertugas di bagian pendaftaran rawat inap dan IGD, serta 3 orang yang bertugas di bagian filing. Terdapat petugas dibagian pendaftaran rawat jalan yang melanjutkan

\section{METODE PENELITIAN}

Jenis penelitian yang digunakan adalah deskriptif dengan pendekatan cross sectional sedangkan rancangan penelitian adalah fenomelogi. Metode yang digunakan dalam dalam penentuan sampel adalah non probability sampling yaitu teknik sampling yang memberi peluang atau kesempatan tidak sama bagi setiap unsur untuk dipilih menjadi sampel. pendidikannya sehingga dalam tugasnya bekerja harus digantikan oleh petugas dibagian filing. Petugas filing merangkap tugasnya menjadi petugas pendaftaran. Menyebabkan beban kerja dari petugas tinggi yaitu adanya double job dan petugas dalam menjalankan tugasnya tidak sesuai dengan tupoksi.

Standar operasional prosedur (SOP) yang digunakan saat ini yaitu tahun 2018, didalam SOP tersebut belum terdapat standar pelayanan minimal lama waktu penyediaan dokumen rekam medis. Belum ditetapkan standar pelayanan tersebut, menjadi pelayanan tersebut belum standar waktu penyediaan dokumen rekam medic pelayanan rawat jalan standar $\leq 10$ menit, sehingga berpengaruh kepada mutu pelayanan. Menyebabkan efektifitas pelayanan tidak bisa diukur secara pasti. Oleh karena itu, penulis ingin menghitung kebutuhan tenaga rekam medis dan

menganalisis beban kerja guna perencanaan tenaga rekam medis untuk melaksanakan kegiatan pengelolaan TPPRJ, TPPRI dan IGD, filing. Berdasarkan uraian di atas maka peneliti tertarik untuk meneliti mengenai "Analisis Kebutuhan Tenaga Rekam Medis Menggunakan Metode workload indicator staff need (WISN) di UPTD Puskesmas Weru".

Instrumen yang digunakan antara lain pedoman observasi dan pedoman wawancara. Subjek dalam penelitian ini adalah tenaga rekam medis yang berjumlah3 orang petugasyaitu 1 orang petugas di TPPRJ, 1 orang petugas di bagianfiling, 1 orang petugas di bagian TPPRI dan TPPGD di UPTD Puskesmas Weru.

Prosedur pengolahan data yang digunakan dalam penelitian ini yaitu editing, tabulasi dan penyajian data. Sedangkan, analisis data pada penelitian 
ini dengan cara menghitung kebutuhan tenaga di unit rekam medis dengan menggunakan metode workload indicator staff need (WISN).

\section{HASIL}

Untuk menghitung kebutuhan SDM tenaga rekam medis di UPTD Puskesmas Weru dibutuhkan data jumlah kunjungan pasien rawat jalan dan rawat inap pada tahun 2020 maka dibutuhkan data kunjungan pasien rawat jalan dan rawat inap pada tahun 20172019.

Tabel 1. Jumlah Kunjungan Pasien Tahun 2017 sampai 2019 di UPTD Puskesmas Weru

\begin{tabular}{ccc}
\hline \multirow{2}{*}{ Tahun } & \multicolumn{2}{c}{ Jumlah Kunjungan Pasien } \\
\cline { 2 - 3 } & Rawat Jalan & Rawat Inap \\
\hline 2017 & 79.485 & 2.112 \\
2018 & 65.595 & 1.920 \\
2019 & 55.569 & 1.828 \\
\hline
\end{tabular}

Untuk penghitungan jumlah kunjungan pada tahun 2020 dapat dihitung menggunakan rumus kuadrat terkecil, maka ditemukan hasil 42.009 pasien rawat jalan dan 1.669 pasien rawat inap yang akan berkunjung di UPTD Puskesmas Weru pada tahun 2020.

\section{Waktu Kerja Tersedia di Unit Rekam Medis UPTD Puskesmas Weru}

Untuk menghitung waktu kerja tersedia menggunakan rumus :

$$
\mathrm{WKT}=\{\mathrm{A}-(\mathrm{B}+\mathrm{C}+\mathrm{D}+\mathrm{E})\} \mathrm{X} \mathrm{F}
$$

Keterangan :
A : Hari Kerja
B : Cuti Tahunan
$\mathrm{C}$ : Pendidikan dan Pelatihan
D : Hari Libur Nasional
E : Ketidakhadiran Kerja
F : Waktu Kerja

Tabel 2. Waktu Kerja Tersedia di Unit Rekam Medis UPTD Puskesmas Weru

\begin{tabular}{cll}
\hline Kode & \multicolumn{1}{c}{ Faktor } & \multicolumn{1}{c}{ Keterangan } \\
\hline A & Hari Kerja & 312 hari/tahun \\
B & Cuti Tahunan & 12 hari/tahun \\
C & Pendidikan dan & 1 hari/tahun \\
& Pelatihan & \\
D & Hari libur Nasional & 24 hari/tahun \\
E & Ketidakhadiran & 0 hari/tahun \\
& Kerja & \\
F & Waktu Kerja & 7 jam/hari \\
& & 1.925 jam/tahun \\
& & $115.500 \quad$ menit/ \\
tahun
\end{tabular}

Berdasarkan perhitungan pada tabel 2 diketahui bahwa waktu kerja tersedia yang diperoleh selama satu tahun di unit rekam medis UPTD

Puskesmas Weru adalah 1.925 jam/tahun atau 115.500 menit/tahun.

\section{Unit Kerja dan Kategori SDM di Unit Rekam Medis UPTD Puskesmas Weru}

Tenaga kerja pada rekam medis di UPTD Puskesmas Weru terdiri dari 3 unit yaitu pendaftaran rawat jalan, filing, pendaftaran rawat inap dan IGD.

\section{Standar Beban Kerja di Unit Rekam Medis UPTD Puskesmas Weru}

Standar beban kerja untuk suatu kegiatan pokok disusun berdasarkan waktu yang dibutuhkan untuk menyelesaikannya dan waktu kerja tersedia yang dimiliki oleh unit masing-masing.

Untuk menghitung standar beban kerja digunakan rumus:

\begin{tabular}{|l|}
\hline Standar beban kerja $=$ \\
Rata-rata waktu per kegiatan pokok
\end{tabular}

Dari perhitungan waktu kerja setahun untuk unit rekam medis didapatkan waktu kerja tersedia yaitu 1.925 jam/tahun atau 115.500 menit/tahun. 
Tabel 3. Penyusunan Standar Beban Kerja

\begin{tabular}{|c|c|c|c|c|c|}
\hline No. & Sub Unit & Kegiatan Pokok & $\begin{array}{l}\text { WKT } \\
\text { (menit) }\end{array}$ & $\begin{array}{c}\text { Rata-rata } \\
\text { WaktuTersedia } \\
\text { (menit) }\end{array}$ & SBK (menit) \\
\hline \multirow[t]{5}{*}{1.} & TPPRJ & Mengentri data pasien lama & 115.500 & 1,5 & 77.000 \\
\hline & & Mencetak resep & 115.500 & 0,5 & 231.000 \\
\hline & & Mengentri data pasien baru & 115.500 & 2,4 & 48.125 \\
\hline & & $\begin{array}{l}\text { Menulis buku register untuk } \\
\text { pasien baru }\end{array}$ & 115.500 & 1,2 & 96.250 \\
\hline & \multicolumn{4}{|c|}{ Jumlah } & 452.375 \\
\hline \multirow[t]{8}{*}{2.} & Filing & Mengambil resep & 115.500 & 0,8 & 144.375 \\
\hline & & Menulis tracer & 115.500 & 0,5 & 231.000 \\
\hline & & $\begin{array}{l}\text { Pengambilan DRM di rak filing } \\
\text { Mencetak formulir pasien baru }\end{array}$ & 115.500 & 0,24 & 481.250 \\
\hline & & & 115.500 & 0,12 & 962.500 \\
\hline & & Perakitan DRM baru & 115.500 & 0,15 & 770.000 \\
\hline & & Mendistribusikan DRM ke poli & 115.500 & 1,8 & 64.167 \\
\hline & & Menyimpan DRM & 115.500 & 1,2 & 96.250 \\
\hline & & Jumlah & & & 2.749 .542 \\
\hline \multirow[t]{4}{*}{3.} & $\begin{array}{l}\text { TPPRI } \\
\text { dan UGD }\end{array}$ & $\begin{array}{l}\text { Mengentri data pasien rawat inap } \\
\text { ke komputer }\end{array}$ & 115.500 & 1,60 & 72.188 \\
\hline & & $\begin{array}{l}\text { Melengkapi status/ DRM pasien } \\
\text { rawat inap }\end{array}$ & 115.500 & 10,50 & 11.000 \\
\hline & & Menulis buku kunjungan & 115.500 & 0,45 & 256.667 \\
\hline & & $\begin{array}{l}\text { Mengentri data pasien rawat inap } \\
\text { atau UGD }\end{array}$ & 115.500 & 1,44 & 80.208 \\
\hline \multicolumn{5}{|c|}{ Jumlah } & 420.063 \\
\hline \multicolumn{3}{|c|}{ Standar Kelonggaran di Unit Rekam } & $\begin{array}{l}\text { a. Waktu } \\
\text { jam/tah }\end{array}$ & kerja tersedia & $=1.925$ \\
\hline \multicolumn{3}{|c|}{$\begin{array}{l}\text { Medis UPTD Puskesmas Weru } \\
\text { Faktor kelonggaran yaitu waktu }\end{array}$} & $\begin{array}{l}\text { b. Standar } \\
\text { jam/tah }\end{array}$ & kelonggaran & 0,15 \\
\hline
\end{tabular}

yang digunakan dalam melaksanakan kegiatan di luar dari kegiatan pokok seperti rapat.

Tabel 4. Waktu Kelonggaran Petugas Rekam Medis di UPTD Puskesmas Weru

\begin{tabular}{clll}
\hline No. & Faktor Kelonggaran & $\begin{array}{c}\text { Rata- } \\
\text { rata } \\
\text { waktu }\end{array}$ & SK \\
\hline 1. & Apel & $\begin{array}{l}\text { jam/ } \\
\text { hari }\end{array}$ & 0,14 \\
2. & Rapat & 3 jam/ & 0,01 \\
& & bulan & 0,15 \\
\hline
\end{tabular}

Standar kelonggaran di unit rekam medis UPTD Puskesmas Weru adalah 0,15 dengan faktor kelonggaran yaitu apel dan rapat.

\section{Kebutuhan Tenaga Kerja di Unit Rekam Medis UPTD Puskesmas Weru}

Perhitungan kebutuhan tenaga kerja di unit rekam medis UPTD Puskesmas Weru dibutuhkan data-data yaitu:
Tabel 5. Jumlah Kunjungan Pasien Tahun 2020 di UPTD Puskesmas Weru

\begin{tabular}{clc}
\hline NO. & Kategori Pasien & $\begin{array}{c}\text { Jumlah Pasien } \\
\text { Tahun 2020 }\end{array}$ \\
\hline 1. & Rawat Jalan & 42.009 \\
2. & Rawat Inap & 1.669 \\
\hline
\end{tabular}

Tabel 6. Kebutuhan SDM di Unit Rekam Medis UPTD Puskesmas Weru

\begin{tabular}{|c|c|c|}
\hline No. & Kegiatan & Kebutuhan SDM \\
\hline 1. & TPPRJ & 2 \\
\hline 2. & Filing & 2 \\
\hline 3. & TPPRI dan UGD & 1 \\
\hline & Jumlah & 5 \\
\hline
\end{tabular}
didapatkan hasil yaitu 5 orang petugas. Hal ini disimpulkan bahwa kebutuhan SDM petugas di unit rekam medis UPTD Puskesmas Weru membutuhkan penambahan 1 orang tenaga dibagian TPPRJ. 


\section{PEMBAHASAN}

Beban Kerja Pegawai Rekam Medis di UPTD Puskesmas Weru

Berdasarkan hasil penelitian yang dilakukan di unit rekam medis UPTD Puskesmas Weru bahwa kegiatan 7 orang pegawai di antaranya D3 rekam medis sebanyak 1 orang dan sekaligus menjabat sebagai kepala unit rekam medis dan bagian filing. Beban kerja dilihat dari kegiatan yang dilakukan petugas pada waktu kerja, baik kegiatan langsung maupun tidak langsung. Sumber daya manusia yang tersedia di sarana kesehatan berkaitan erat dengan beban kerja. Hal ini sesuai dengan teori Ilyas (2011), beban kerja dapat dilihat dari kegiatan yang dilakukan petugas pada waktu kerja baik kegiatan langsung, tidak langsung dan kegiatan lain. Asriati (2019), menyatakan bahwa perlunya pengelolaan SDM kesehatan khususnya perencanaan SDM kesehatan. a. Waktu kerja tersedia di UPTD

Puskesmas Weru

Hasil penelitian didapatkan bahwa waktu kerja tersedia petugas TPPRJ, TPPRI dan IGD, filing di unit rekam medis UPTD Puskesmas Weru dalam satu tahun adalah 1.925 jam/tahun atau 115.500 menit/tahun.

Berdasarkan hasil penelitian dari Saputri, et.al (2009), waktu kerja produktif di Puskesmas adalah 3,5 jam. Artinya, sebanyak 58,33\% waktu kerja produktif per hari

digunakan untuk memberikan pelayanan langsung kepada pasien dan sisanya $41,67 \%$ digunakan untuk kegiatan lain. Penelitian ini waktu kerja produktif di Puskesmas adalah 5 jam.

b. Standar beban kerja di UPTD

Puskesmas Weru

Berdasarkan penghitungan beban kerja di unit rekam medis UPTD Puskesmas Weru, diketahui bahwa bagian pendaftaran rawat jalan ialah 452.375 menit, bagian filing ialah 2.749 .542 menit, dan 
bagian pendaftaran rawat inap atau UGD ialah 420.063 menit. Diketahui bahwa bahwa rata-rata beban kerja setiap bagian di unit rekam medis UPTD Puskesmas Weru masih tinggi sehingga membuat beban kerja petugas rekam medis masih tinggi.

c. Standar kelonggaran di UPTD Puskesmas Weru

Kegiatan kelonggaran di unit rekam medis UPTD Puskesmas Weru adalah apel dan rapat, dengan jumlah standar kelonggaran yaitu 0,15 menit/tahun. Berdasarkan penelitian sebelumnya milik Ruth (2010) dalam

(Rahmawati, 2015) standar kelonggaran dipengaruhi oleh rata-rata waktu kelonggaran sebesar 5\% dari jumlah jam kerja petugas dan waktu kerja yang tersedia. Bila rata-rata waktu kelonggaran memiliki

kebijakan tentang standar kelonggaran maka produktivitas

petugas dapat dimaksimalkan. Standar kelonggaran didapatkan dari faktor kelonggaran tiap kategori tenaga meliputi jenis kegiatan dan

kebutuhan waktu untuk menyelesaikan suatu kegiatan yang

tidak terkait langsung atau dipengaruhi tinggi rendahnya kuantitas pokok pelayanan.

d. Penghitungan kebutuhan tenaga kerja di UPTD Puskesmas Weru

Hasibuan (2016) menyatakan bahwa perencanaan sumber daya manusia akan dilakukan dengan baik dan benar jika perencanaannya mengetahui apa dan bagaimana

sumber daya manusia itu. Perhitungan kebutuhan tenaga kerja menggunakan rumus WISN yaitu 5 tenaga. Penambahan petugas di bagian TPPRJ 1 orang petugas.

Penelitian yang dilakukan oleh Jayanti, Indra \& Cahyo (2019), tentang perencanaan kebutuhan petugas rekam medis bagian penerimaan pasien di Puskesmas dengan metode ABK. Adapun hasil 
penelitian didapatkan jumlah petugas penerimaan pasien dengan standar

beban kerja 102.685 menit dibutuhkan sebanyak 8 petugas.

\section{SIMPULAN}

1. Waktu kerja tersedia di unit rekam medis UPTD Puskesmas Weru pada tahun 2020 ialah 1.925 jam/tahun atau $115.500 \mathrm{menit} /$ tahun.

2. Standar beban kerja di unit rekam medis UPTD Puskesmas Weru bahwa bagian pendaftaran rawat jalan ialah 452.375 menit, bagian filing ialah 2.749 .542 menit, dan bagian pendaftaran rawat inap atau UGD adalah 420.063 menit.

3. Standar kelonggaran di unit rekam medis UPTD Puskesmas Weru adalah $0,15 \mathrm{jam} /$ tahun.

4. Jumlah perkiraan kebutuhan tenaga kerja di unit rekam medis UPTD Puskesmas Weru tahun 2020 dengan menggunakan metode workload indicator staff need (WISN) dibutuhkan penambahan 1 petugas.

\section{UCAPAN TERIMAKASIH}

Selama pelaksanaan penelitian ini, banyak pihak yang telah berjasa dalam memberikan kesempatan, memotivasi, dan waktu serta pikiran. Ucapan terimakasih penulis sampaikan kepada:

1. Titik Haryanti, S.KM., M.P.H. selaku Dekan Fakultas Kesehatan Masyarakat Universitas Veteran Bangun Nusantara Sukoharjo.

2. Fahmi Hakam, S.KM., M.P.H. selaku Ketua Prodi DIII Rekam Medis dan Informasi Kesehatan Fakultas Kesehatan Masyarakat Universitas Veteran Bangun Nusantara Sukoharjo dan juga sebagaiPembimbingI dalampenyusunanKarya Tulis Ilmiah.
3. Yul Asriati, S. Psi., M.P.H. selaku Pembimbing II dalam penyusunan Karya Tulis Ilmiah

4. dr. Dewi Kartikasari selaku Kepala UPTD Puskesmas Weru yang telah memberikan kesempatan kepada peneliti dalam melaksanakan penelitian.

5. Sri Wahyuni, A.Md. PK. selaku Kepala Instalasi Rekam Medis UPTD Puskesmas Weru yang telah membimbing dan memberikan arahan kepada peneliti dalam menyelesaikan KTI.

6. Bapak/Ibu Dosen DIII Rekam Medis dan Informasi Kesehatan Fakultas Kesehatan Masyarakat Universitas Veteran Bangun Nusantara Sukoharjo.

7. Rekan-rekan mahasiswa DIII Rekam Medis dan Informasi

KesehatanUniversitas Veteran Bangun Nusantara Sukoharjo yang telah membantu dalam penyusunan KTI ini.

\section{DAFTAR PUSTAKA}

Asriati, Y. 2019. Analisis Perencanaan Sumber Daya Manusia Dengan Metode WISN Pada Petugas Rekam Medis Rumah Sakit X Di Surakarta Jawa Tengah. Prodi Rekam Medis dan Informasi Kesehatan Fakultas Kesehatan Masyarakat Universitas Veteran Bangun Nusantara.

Hasibuan, Drs. H.Malayu S.P. 2016. Manajemen Sumber Daya Manusia. Jakarta: Bumi Aksara.

Ilyas, Y. 2011. Perencanaan SDM Rumah Sakit. Jakarta: Pusat Kajian Ekonomi Kesehatan FKM UI.

Jayanti, K dkk. 2019. Perencanaan Kebutuhan Petugas Rekam Medis Bagian Penerimaan Pasien di Puskesmas dengan Metode ABK. 
Fakultas Ilmu Kesehatan. Institut Ilmu Kesehatan Bhakti Wiyata.

Permenkes RI. 2019. Keputusan Menteri Kesehatan Nomor 43 Tahun 2019 tentang Pusat Kesehatan Masyarakat. Jakarta.

Rahmawati, N. 2015. Analisis Kebutuhan Jumlah Tenaga Kerja Berdasarkan Beban Kerja di Unit Rekam Medis RSU Assalam Gemolong. Prosiding Nasional APIKES-AKBID Citra Medika Surakarta.

Saputri V, dkk. 2009. Perencanaan Kebutuhan Sumber Daya Manusia Kesehatan Dengan Metode Workload Indicators Of Staffing Need (WISN) Di Puskesmas Merdeka Kota Palembang Tahun 2009.

Sutadji. 2010. Perencanaan dan Pengembangan Sumber Daya Manusia. Yogyakarta: Dee Publish 
Jurnal Manajemen Informasi dan Administrasi Kesehatan (JMIAK)

ISSN: 2621-6612 | Email: jmiakmedrec@gmail.com

Volume 03 Nomor 02 November 2020 Halaman 27-34 